\title{
ЗАКОНОДАВЧЕ ЗАБЕЗПЕЧЕННЯ ПУБЛІЧНО-ПРИВАТНОГО ПАРТНЕРСТВА В СІЛЬСЬКІЙ МІСЦЕВОСТІ
}

Іваненко М. М.

У статmі автором здійснено аналіз адміністративно-правового регулювання суспільно-економічних відносин розвитку сільської місцевості. У результаті аналізу встановлено, що забезпечення такого розвитку не може бути реалізовано суто засобами державного регулювання адміністративно-територіального устрою, а повинно формуватися на засадах комплексного забезпечення діяльності суб'єктів аграрного сектора, їхньої взаємодії з місцевими орга нами виконавчої влади та самоврядування. Доведено, що адміністративне регулювання суспільно-економічних відносин являє собою, поряд із центральними органами держави, діяльність органів регіонального самоуправління, робота яких спрямована на збалансованість інтересів суб'єктів господарювання за допомогою законів на принципах самовідтворення, самоуправління і самофінансування.

3 метою визначення сучасного стану правового регулювання та перспектив публічно-приватного партнерства суб'єктів аграрного сектора з органами місцевого самоврядування щодо розвитку сільської місцевості здійснено аналіз базових аграрних законів («Про пріоритетність соціального розвитку села та агропромислового комплексу в народному господарстві», «Про державну підтримку сільського господарства України», «Про основні засади державної аграрної політики на період до 2015 року»), окремих підзаконних нормативно-правових актів. Визначено наявність у цих актах окремих, не узгоджених один з одним, механізмів реалізації публічно-приватного партнерства в напрямі розвитку сільськогосподарського виробництва, сільських територій та повноважень чи обов'язків місцевих органів влади щодо фінансування з місцевих бюджетів окремих соціальних чи екологічних заходів.

Встановлено, що результатом розвитку суспільно-економічних та політико-правових відносин децентралізації влади стало зростання ролі органів місцевого самоврядування в забезпеченні розвитку сільських територій. Зроблено висновки про подальшу доцільність публічно-приватного партнерства в аграрному секторі загалом і в окремих видах сільськогосподарської діяльності. Запропоновано як

(C) Іваненко М. М., 2020 спосіб удосконалення адміністративно-правового механізму здійснення такого партнерства ухвалення окремого закону, який міститиме єдиний системний nідхід до комплексного забезпечення розвитку парmнерства органів місцевого самоврядування та суб' $є$ тів аграрного підприємництва.

Ключові слова: аграрний сектор, адміністративно-правове регулювання, законодавство, публічно-приватне партнерство, орган місцевого самоврядування, сільська територіальна громада.

Ivanenko M. M. Legislative support of public-private partnership in rural areas

In the article the author analyzes the administrative and legal regulation of socio-economic relations of rural development. As a result of the analysis it was established that ensuring such development cannot be realized exclusively by means of state regulation of the administrative-territorial system, but should be formed on the basis of comprehensive support of agricultural sector entities and their interaction with local executive bodies and self-government. It is proved that the administrative regulation of socio-economic relations is a number of central government, the activities of regional governments, whose work is aimed at balancing the interests of economic entities through laws on the principles of self-reproduction, self-government and self-financing.

In order to determine the current state of legal regulation and prospects of public-private partnership of agricultural sector entities with local governments on rural development, an analysis of basic agricultural laws ("On the priority of social development of rural and agro-industrial complex in the national economy", "On state support of agriculture of Ukraine", "On the basic principles of state agricultural policy for the period up to 2015") and certain bylaws. These acts identify separate, uncoordinated mechanisms for implementing public-private partnerships in the development of agricultural production and rural areas and the powers or responsibilities of local authorities to finance certain social or environmental activities from local budgets.

It is established that the result of the development of socio-economic and political-legal relations of decentralization of power was the growth of the role of local governments in ensuring the development of rural areas. Conclusions are made on the further expediency of pub- 
lic-private partnership in the agricultural sector as a whole and in certain types of agricultural activities. It is proposed as a way to improve the administrative and legal mechanism for such a partnership, the adoption of a separate law that will contain a single systematic approach to comprehensive support for the development of partnerships between local governments and agricultural enterprises.

Key words: agricultural sector, administrative and legal regulation, legislation, public-private partnership, local self-government body, rural territorial community.

Постановка проблеми та їі актуальність. Адміністративно-правове регулювання суспільно-економічних відносин розвитку сільської місцевості $\epsilon$ стратегічним напрямом державної політики України. Однак забезпечення такого розвитку не може бути реалізовано суто засобами державного регулювання відносин адміністративно-територіального розвитку. Оскільки «сільська місцевість - це територія, що знаходиться за межами міст і $\epsilon$ переважно зоною сільськогосподарського виробництва та сільської забудови» [1], то система нормативно-правового регулювання визначених відносин повинна формуватися на засадах комплексного забезпечення діяльності суб'єктів аграрного сектора, їхньої взаємодії з органами місцевого самоврядування щодо забезпечення соціально-культурних та інших умов існування сільського населення.

Нині система адміністративно-правового регулювання відносин у сільській місцевості характеризується наявністю значної кількості законодавчих актів різного галузевого спрямування. Актуальним для характеристики сучасного стану та визначення перспектив такого регулювання $\epsilon$ аналіз законів, якими закріплено концептуальні засади регулювання відносин сільськогосподарського виробництва, розвитку сільських територій тощо, місця і ролі в цьому процесі взаємодії суб'єктів аграрного сектора з органами місцевого самоврядування.

Аналіз останніх досліджень і публікацій. Дослідженню питань нормативно-правового регулювання відносин розвитку сільських територій, участі в цьому процесі сільськогосподарських виробників, органів місцевого самоврядування, громадських організацій та інших суб'єктів присвячені роботи фахівців у галузі адміністративного, фінансового й аграрного права, економіки, державного управління тощо. Особливу увагу варто звернути на праці таких учених, як: О.В. Алейнікова, В. М. Анікеєнко, О.І. Гузій, М.Ф. Кропивко, В.І. Курило, В.В. Мушенок, О.П. Світличний, А.М. Статівка, Н.І. Титова, В.Ю. Уркевич,
Н.В. Хміль та інші. Однак нині немає комплексних досліджень питань повноти формування, ступеня законодавчого закріпленого, ефективності функціонування адміністративно-правового механізму реалізації заходів публічно-приватного партнерства органів місцевого самоврядування та суб'єктів аграрного сектора щодо розвитку сільської місцевості та сільських територіальних громад. Зазначені обставини сформували авторський інтерес до дослідження.

Метою статті $\epsilon$ здійснення аналізу базових нормативно-правових актів законодавства, що регулюють відносини в аграрному секторі економіки України, на предмет забезпечення ними відносин публічно-приватного партнерства між територіальними громадами, в особі органів місцевого самоврядування, та суб'єктами аграрного сектора, а також визначення законодавчих пріоритетів такого партнерства, зазначення недоліків, надання пропозицій щодо підвищення ефективності адміністративно-правового забезпечення такого партнерства.

Виклад основного матеріалу. В умовах побудови сучасних соціально-економічних відносин в Україні адміністративно-правове регулювання розвитку сільськогосподарського виробництва та соціальної інфраструктури сільської місцевості спрямоване насамперед на створення відповідних умов для саморегулювання ринкових відносин за допомогою нормативно-правових актів. Поступове формування ринку на засадах малого державного (адміністративне й економічне) регулювання «приводить до збалансування складових елементів системи та постановки конкретних цілей, розроблення масштабних проєктів і державних програм» [2, с. 61].

Тобто в сучасних умовах перехідного періоду національної економіки від адміністративно-командної системи до соціальних ринкових відносин адміністративне регулювання комплексного розвитку виробничих, соціальних, екологічних, інфраструктурних елементів сільської місцевості $\epsilon$ необхідним і таким, що повинно динамічно трансформуватися від тотального контролю за розвитком аграрного сектора до виконання функцій: контролю за цільовим та раціональним використанням природних ресурсів; заохочення приватних виробників сільськогосподарської продукції до органічного господарювання та вирощування потрібних українському суспільству культур, розв'язання перспективних завдань розвитку сільської місцевості, зважаючи на особливий стан та можливості кожного регіону. 
Отже, з огляду на наукову позицію С.В. Мочерного про те, що адміністративне регулювання - це дії не лише адміністрації країни, а й регіонів, які «спрямовані на збалансованість інтересів суб' $є$ ктів господарювання за допомогою правових законів на принципах самовідтворення, самоуправління і самофінансування» [2, с. 112], здійснимо аналіз адміністративно-правового регулювання органами місцевого самоврядування відносин в аграрному секторі України.

Основою для формування авторського бачення проблеми $\epsilon$ результати наукових досліджень B.І. Курила про визначення «аграрного сектора як сільськогосподарської галузі економіки та інших галузей, які забезпечують виробництво будь-яких засобів виробництва сільськогосподарської продукції, iï переробки, зберігання та реалізацію» [3, с. 90], а також про характеристику спільних ознак виробничої сільськогосподарської галузі та соціальної інфраструктури сільської місцевості, яку науковець характеризує як «спільність території (як просторовий базис сільськогосподарського виробництва та проживання сільських мешканців); єдність населення (сільські мешканці, як правило, зайняті в сільськогосподарському виробництві); спільність соціально-трудових інтересів сільського населення, оскільки вони безпосередньо заінтересовані в розвитку сільськогосподарського виробництва, і соціальної інфраструктури сільської місцевості» [3, с. 91].

Відповідно до наукової позиції здійснимо аналіз спеціальних нормативно-правових актів, які забезпечують державне регулювання відносин сільськогосподарського виробництва, його соціально-територіальної підтримки («здійснення державної підтримки сільського господарства В контексті надання підтримки сільським територіям, сільській інфраструктурі, селу загалом» [4, с. 37]) на предмет наявних повноважень щодо такого регулювання в органів місцевого самоврядування сіл.

Отже, насамперед варто звернути увагу на Закон України «Про пріоритетність соціального розвитку села та агропромислового комплексу в народному господарстві» від 17 жовтня 1990 р. № 400-XII, ухвалений для забезпечення умов, змісту та меж пріоритетності розвитку соціальної сфери села й агропромислового комплексу у структурі народного господарства, сприяння соціальній захищеності сільського населення [5].

Аналіз норм зазначеного вище Закону дає підстави зробити узагальнення про те, що на початку процесу українського державотворення та форму- вання основних засад адміністративно-правового регулювання суспільних відносин на селі роль органів місцевого самоврядування (регіональне самоврядування) обмежується лише повноваженнями: 1) фінансування 3 місцевих бюджетів будівництва в сільській місцевості об'єктів соціальної інфраструктури; 2) розпорядника цільових державних централізованих капіталовкладень у соціальну сферу села, який несе юридичну відповідальність разом з іншими учасниками інвестиційного процесу за цільове й ефективне їх використання (ст. 6) [5].

Отже, у початковий період формування системи адміністративно-правового регулювання соціального розвитку села й агропромислового комплексу здебільшого переважає парадигма державного сприяння даному суспільно-економічному процесу. Однак варто зазначити епізодичну наявність у цьому законодавчому механізмі органів місцевого самоврядування та суб'єктів аграрного сектора (агропромисловий комплекс), яким Законом передбачалося «відшкодування коштів з місцевого бюджету за побудову об'єктів соціальної інфраструктури» [5]. Вкладання коштів суб'єктами аграрного сектора в розбудову соціальної інфраструктури сільських територій можна вважати елементом визначеного А.М. Статівкою такого виду публічно-приватного партнерства, як «внесення приватним інвестором інвестицій в об'єкти партнерства із джерел, не заборонених законодавством» [6, с. 25], що відповідає одному 3 основних принципів державно-приватного партнерства - «узгодження інтересів державних та приватних партнерів з метою отримання взаємної вигоди» (п. 1 ст. 3) [7].

Розглянемо Закон України «Про державну підтримку сільського господарства України" від 24 червня 2004 р. № 1877-IV, який «визначає основи державної політики в бюджетній, кредитній, ціновій, регуляторній та інших сферах державного управління щодо стимулювання виробництва сільськогосподарської продукції та розвитку аграрного ринку, а також забезпечення продовольчої безпеки населення» [8]. Визначимо, за преамбулою, даний нормативно-правовий акт $\epsilon$ документом, який регулює суто виробничо-господарські відносини в аграрному секторі та безпосередньо не зачіпає питання соціального розвитку сільських територій.

Серед законодавчо закріплених напрямів співпраці суб'єктів аграрного сектора 3 органами місцевого самоврядування варто звернути увагу на категорію «місцеві потреби» - «потреби 
територіальної громади в обсягах сільськогосподарської продукції для їх споживання бюджетними установами та організаціями, утримання яких здійснюється за рахунок коштів місцевого бюджету в межах власних або делегованих повноважень такої територіальної громади» (п. 2.8 ст. 2) [8]. На нашу думку, територіальна громада має право на задоволення власних потреб у сільськогосподарській продукції шляхом їі замовлення та закупівлі в суб'єктів аграрного сектора, які здійснюють свою виробничу діяльність цілком чи частково в межах території відповідної територіальної громади.

Особливістю такої співпраці може стати договірне закріплення великої кількості взаємовигідних умов для обох сторін, найбільш сприятливими 3 яких є: для суб'єкта аграрного сектора - отримання попередньої оплати, тобто додаткове залучення фінансових ресурсів на період вирощування чи виробництва продукції; для територіальної громади - здійснення спостереження за процесом виробництва продукції на предмет встановлення надмірного застосування шкідливих засобів, отримання можливості використання продукції за потребою, що приведе до уникнення псування такої продукції та додаткових витрат з іiі зберігання тощо.

Отже, Закон України «Про державну підтримку сільського господарства України» визначає основи державної політики у сфері матеріального аграрного виробництва в Україні, а також ключову роль держави в цьому процесі, проте містить норми адміністративного регулювання відносин публічно-приватного партнерства органів місцевого самоврядування та суб'єктів аграрного сектора.

Ще одним нормативно-правовим актом, що регулює адміністративно-правові засади відносин суб'єктів аграрного сектора з органами місцевого самоврядування, $\epsilon$ Закон України «Про основні засади державної аграрної політики на період до 2015 р.» від 18 жовтня 2005 р. № 2982-IV, який, відповідно до преамбули, визначає, поряд із «пріоритетністю розвитку агропромислового комплексу, важливість соціального розвитку села в національній економіці та потреби відродження селянства як господаря землі, носія моралі та національної культури» [9].

Аналіз даного Закону дає підстави зробити припущення про те, що з розвитком суспільно-економічних та політико-правових відносин в Україні більшої ваги набирає питання участі органів місцевого самоврядування в забезпеченні розвитку сільських територій. Адже в цьому Закону міститься норма про те, що «основні засади державної аграрної політики спрямовані на забезпечення сталого розвитку аграрного сектора національної економіки, системності та комплексності під час здійснення заходів з реалізації державної аграрної політики всіма органами місцевого самоврядування» (ст. 1) [9].

Основними пріоритетами співпраці суб'єктів аграрного сектора з органами місцевого самоврядування Закон України «Про основні засади державної аграрної політики на період до 2015 р.» визначає підтримку доходів таких суб'єктів шляхом запровадження «дотацій місцевих бюджетів на утримання маточного поголів'я тварин, посівів стратегічно важливих видів сільськогосподарських культур, збільшення фінансової підтримки господарств у регіонах з несприятливими для ведення сільського господарства природно-кліматичними умовами» (абз. 5 п. 2 ст. 1) [9].

Аналіз базових законів про функціонування і розвиток аграрного сектора та соціальної інфраструктури села дає підстави здійснити узагальнення щодо відсутності закріпленої в них стратегії публічно-приватного партнерства органів місцевого самоврядування та суб'єктів аграрного сектора, а лише наявні поодинокі епізодичні механізми адміністративно-правового регулювання аграрних виробничо-соціально-територіальних відносин. У системі законодавства України про регулювання відносин в аграрному секторі нині немає комплексного галузевого законодавчого акта, який урегульовував би взаємовигідні відносини зазначених вище суб'єктів, а також пріоритетні напрями їхніх спільних дій щодо розвитку сільських територій.

Проте зазначимо, що окремі чинні законодавчі та підзаконні нормативно-правові акти (розпорядження Ради Міністрів України «Про додаткові заходи щодо розвитку індивідуального житлового будівництва на селі та поліпшення соціально-демографічної ситуації у трудонедостатніх господарствах» від 15 грудня 1990 р. № 369 [10], постанова Верховної Ради України «Про ситуацію в агропромисловому комплексі України» від 4 жовтня 1996 р. № 408/96-ВР [11], Указ Президента України «Про Основні засади розвитку соціальної сфери села» від 20 грудня 2000 р. № 1356/2000 [12], закони України «Про стимулювання розвитку сільського господарства на період 2001-2004 рр. від 18 січня 2001 р. № 2238-III [13], «Про особливості страхування сільськогосподарської продукції з державною підтримкою» від 9 лютого 2012 р. № 4391-VI [14]), які регулюють 
окремі напрями розвитку аграрного сектора, економічного розвитку сільських територій, захисту природних ресурсів тощо, не містять вказівок на необхідність співпраці між органами місцевого самоврядування та суб'єктами аграрного сектора, а лише в окремих випадках, тією чи іншою мірою визначають повноваження чи обов'язки місцевих органів влади щодо фінансування з місцевих бюджетів окремих соціальних чи екологічних заходів.

Уперше в нормативно-правовій системі України необхідність та способи співпраці органів місцевого самоврядування та суб'єктів аграрного сектора були закріплені в Концепції розвитку сільських територій, яка схвалена розпорядженням Кабінету Міністрів України від 23 вересня 2015 р. № 995-р [16], у якій центральний орган виконавчої влади визнає, що основними причинами погіршення соціально-економічного й екологічного стану сільських територій (поряд з іншими причинами) $є$ : «низька ефективність органів місцевого самоврядування у вирішенні проблемних питань розвитку сільських територій та відведення недостатньої ролі у процесах реформування аграрного сектора економіки» [16].

3 огляду на прописані в Концепції завдання, здійснимо узагальнення про те, що першим кроком до подолання описаних у цій статті проблем адміністративно-правового регулювання відносин в аграрному секторі $є$ ухвалення окремого закону України, який міститиме реальний механізм комплексного забезпечення: раціонального формування сільського господарства, диверсифікованої сільської економіки, розвитку сільських територій, сприятливого середовища проживання на основі нарощування людського і соціального капіталу та розвитку партнерства органів місцевого самоврядування та суб'єктів аграрного підприємництва. Практична реалізація такого механізму надасть можливість реформувати систему управління розвитком сільських територій, активізувати ініціативність та відповідальність територіальних громад сіл, селищ, розширити сферу прикладання праці, збільшити доходи сільського населення і доступність базових послуг, нормалізувати демографічну ситуацію на переважній частині сільських територій [15].

Висновки. Підтримуємо думку вітчизняних науковців B.І. Курила та В.В. Мушенка про те, що «стратегія розвитку держави вимагає змін, які повинні бути орієнтовані на регіон, адже ринкова економіка вимагає суттєвого збільшення використання ресурсів на території їх створення» [16, с. 50], зазначимо доцільність розвитку публічно-приватного партнерства в аграрному секторі економіки України, особливо в окремих видах господарської діяльності (будівництво й експлуатація доріг та інших інфраструктурних об'єктів у сільській місцевості, раціональне використання природних ресурсів та поводження 3 відходами сільськогосподарського виробництва тощо). Саме тому потребує вдосконалення та законодавчого закріплення адміністративно-правовий механізм публічно-приватного партнерства між органами місцевого самоврядування та суб'єктами аграрного сектора, що сприятиме зростанню можливостей гарантування продовольчої безпеки окремих регіонів та держави загалом, забезпечення інвестиційної й інноваційної привабливості сільської місцевості, розвитку сільських територій та соціальної сфери в межах територіальних громад.

\section{Література}

1. Про сільськогосподарську дорадчу діяльність : Закон України від 17 червня 2004 р. № 1807-IV. Вiдомості Верховної Ради України. 2004. № 38. Ст. 470.

2. Економічна енциклопедія : у 3-х т. / редкол. : С.В. Мочерний (відп. ред.) та ін. Київ : Видавничий центр «Академія», 2000. Т. 1.864 с.

3. Курило В.І. Про зміст та співвідношення деяких аграрних дефініцій. Економіка аграрно-промислового комплексу. 2014. № 2. С. 87-92.

4. Курило B.І., Мушенок В.В. Фінансово-правове регулювання державної підтримки сільськогосподарського виробництва в Україні : стан та перспективи удосконалення : монографія / за заг. ред. В.І. Курила. Ніжин, 2012. 160 с.

5. Про пріоритетність соціального розвитку села та агропромислового комплексу в народному господарстві : Закон УРСР від 17 жовтня 1990 р. № 400-XII. Відомості Верховної Ради Української Радянської Соціалістичної Республіки. 1990. № 45. Ст. 602.

6. Аграрне право : підручник / В.М. Корнієнко та ін. ; за ред. А.М. Статівки. Харків : Право, 2018. $416 \mathrm{c}$.

7. Про державно-приватне партнерство : Закон України від 1 липня 2010 р. № 2404-VІ. Відомості Верховної Ради України. 2010. № 40. Ст. 524.

8. Про державну підтримку сільського господарства України : Закон України від 24 червня 2004 р. № 1877-IV. Відомості Верховної Ради України. 2004. № 48. Ст. 229.

9. Про основні засади державної аграрної політики на період до 2015 р. : Закон України від 


\section{Правове забезпечення адміністративної реформи}

18 жовтня 2005 р. № 2982-IV. Відомості Верховної Ради України. 2006. № 1. Ст. 17.

10. Про додаткові заходи щодо розвитку індивідуального житлового будівництва на селі та поліпшення соціально-демографічної ситуації в трудонедостатніх господарствах : розпорядження Ради Міністрів України від 15 грудня 1990 р. № 369 (втратило чинність 28 липня 1992 р.). URL: https://zakon.rada.gov.ua/ laws/show/369-90.

11. Про ситуацію в агропромисловому комплексі України : постанова Верховної Ради України від 4 жовтня 1996 р. № 408/96-ВР. Відомості Верховної Ради України. 1996. № 48. Сm. 265.

12. Про основні засади соціального розвитку села : Указ Президента України від 20 грудня 2000 р. № 1356/2000. URL: http://zakon0.rada.gov.ua.

13. Про стимулювання розвитку сільського господарства на період 2001-2004 рр. : Закон України від 18 січня 2001 р. № 2238-III. Відомості Верховної Ради України. 2001. № 11. Ст. 52.
14. Про особливості страхування сільськогосподарської продукції з державною підтримкою : Закон України від 9 лютого 2012 р. № 4391-VI. URL: http: / / zakon2.rada.gov.ua/laws/show/4391-vi.

15. Про схвалення Концепції розвитку сільських територій : розпорядження Кабінету Міністрів України від 23 вересня 2015 р. № 995-p. URL: http:// www.csi.org.ua/pro-rozvytok-silskyh-terytorij-i-ne.

16. Kurylo V.I., Mushenok V.V. Place and the role of local taxes in the functioning of united local communities. Organizational and economic mechanisms of development of the financial system : collective monograph / edited by M.G. Bezpartochnyi. ISMA University. Riga : Landmark SIA, 2016. P. 36-52.

Іваненко М. М., здобувач Київського кооперативного інституту бізнесу і права 